\title{
Effect of Forensic Audit on Bank Fraud in Nigeria
}

\author{
S. J. Inyada, PhD \\ Kogi State University \\ Department of Accounting \\ P. M. B. 1008 \\ Anyigba, Kogi State. \\ D. O. Olopade, $\mathrm{PhD}$ \\ Salem University \\ Department of Accounting \\ Lokoja, Kogi State. \\ John, Ugbede \\ Department of Accounting \\ Kogi State University \\ Anyigba, Kogi State.
}

\begin{abstract}
The main objective of this study is to examine the effect of Forensic Audit on Bank Fraud in Nigeria. The unprecedented increase in cases of bank frauds in Nigeria has made the application of forensic audit an indispensable tool in the audit cycle. Forensic audit skills are contemporary and diagnostic audit tools that help in the detection, prevention and reduction of frauds. Forensic audit skills give not only greater and current insight into the banks' internal control measures and risk management techniques but also made available the technical capability for the detection, prevention and reduction of frauds. This study therefore examines the effect of Forensic Audit on Bank Fraud in Nigeria. The survey design was employed and the sample of the study was 128 out of a population of 165. The data were analyzed using the ordinary least square (OLS) regression model. The findings show that forensic audit helps in an enhanced bank fraud detection and prevention. Furthermore, the results show that forensic audit is not just an effective tool but also an efficient tool for the detection, prevention and reduction of bank fraud in Nigeria. It is therefore recommended that forensic audit should be highly embraced by specialized institutions like bank and insurance companies to ensure that fraud cases are speedily detected and adequately prevented. Also, a separate body should be constitutionally established and mandated for the training and retraining of forensic auditors. It is also recommended that our institutions of higher learning, apart from teaching forensic accounting and auditing, should have standard forensic audit laboratories with the tools for practical study.
\end{abstract}

\section{Introduction}

The credibility of the traditional audit process in the Nigerian banking sector has been of recent the subject of unprecedented concern as a result of the high incidence of failures of banks. The quality of the traditional audit exercise has been questioned because of the high cases of bank frauds that have led to bank failures. The 2004 crises in the banking sector swept away 14 banks in Nigeria (Adeyemi, 2011). In the 2009 CBN forensic test in Nigeria, eight (8) banks were identified by CBN to have failed in capital adequacy and asset quality among other test parameters used and their chief executives removed. These banks that failed the test, were deposit money banks given clean audit bills of health by even international audit firms believed to have high audit quality records. The banks affected in 2009 were Afribank, Oceanic Bank, Intercontinental Bank, Bank PHB, Finbank, Spring Bank and Union Bank. The magnitude of the bank failures in the country therefore became a matter of grave and utmost concern not only to the entire nation in general but to the accounting practitioners and the academia in particular. The application of forensic audit skills seems to be a panacea that will go a long way in assisting in fraud detection, prevention and reduction in the banking industry.

The incidence of bank failures in Nigeria where many highly reputed banks with national and international audit firms as external auditors failed to actually meet the six-factor performance indices of Capital Adequacy, Asset Quality, Management Quality, Earnings, Liquidity and Sensitivity to Market Risk (CAMELS) test of the apex bank in Nigeria, calls for a careful examination of the quality of the traditional audit process. 
CAMELS is an international bank-rating system where bank supervisory authorities like the Central Bank of Nigeria (CBN) rate banking institutions according to six factors. Bank supervisory authorities assign each bank a score on a scale of one (best) to five (worst) for each factor. If a bank has an average score less than two it is considered to be a high-quality institution, while banks with scores greater than three are considered to be less-than-satisfactory establishments. The system helps the supervisory authority identify banks that are in need of attention. The application of forensic audit helps in detection, prevention and reduction of bank fraud. Okafor \& Onwumere (2012) point out that more recently a number of commercial banks have gone under due to reasons related to failure in corporate governance aided by lack of due professional care or negligence in the discharge of auditing functions.

\subsection{Research Problem}

Bank fraud has remained the bane of the growth and development of our economy/society. The unprecedented increase in the number of bank failures as a result of erosions in the quality of traditional audit reports issued by high profiled national and international audit firms leaves much to be desired. The spate of audit failures in the world has brought a great deal of disappointment to investors and other corporate financial reporting stakeholders (Adeyemi, Okpala \& Dabor, 2012). According to Egbo (2011), the massive bank failure in Nigeria was a bitter experience for the economy as it brought untold hardship to depositors who lost their money and lost confidence in the ability of Nigerians to manage a banking business. This alarming increase in the number of bank failures as a result of the high rate of bank frauds has necessitated the application of forensic audit skills to determine the magnitude of the frauds the level of involvement of the perpetrators.

Aguolu (2008) notes that the practice of auditing poses a great deal of challenges to the accounting profession since it are a mirror through which the profession is evaluated by the general public. He continues, the high profile accounting scandals involving large multinational corporations and highly rated professional firms as typified by the Enron and WorldCom experience underscores the need for the accounting profession to take a critical look at the quality of work performed by the members. Also, Modum, Ugwoke \& Onyeanu (2013) in support of a call for an urgent need for a critical look at the quality of work by members of the accounting profession, note that the spate of corporate failures in recent times calls for serious examination of their causes and possible solutions. Okafor (2012) points out that in the Nigerian banking sector, the audit conducted by the Central Bank of Nigeria (CBN) into the activities of some registered banks in 2009 revealed very high level of capital inadequacy, very poor asset quality and ineffective corporate governance system. Indeed, several banks with clean audit reports and outstanding performance indices failed in Nigeria in spite of their satisfactory audit reports. The incident makes the credibility of the statutory audit of these commercial banks and the quality of the audit process highly questionable. The application of forensic audit in the banking sector will continue to add value to audit exercises in the face of the limitations of the traditional audit. The question is, what is actually the effect of forensic audit on bank fraud in Nigeria?

\subsection{Research Objectives}

The main objective of this study is to examine the effect of Forensic Audit on Bank Fraud in Nigeria. The specific objectives of the study are to:

i. Determine the effect of forensic audit on bank fraud detection

ii. Ascertain the effect of forensic audit on bank fraud prevention

\subsection{Research Questions}

The study intends to answer the following salient questions:

i. What is the effect of forensic audit on bank fraud detection?

ii. What is the effect of forensic audit on bank fraud prevention?

\subsection{Research hypotheses}

The following hypotheses are formulated based on the research problems and objectives:

H01: Forensic audit does not have positive effect on bank fraud detection

H02: Forensic audit does not have positive effect on bank fraud prevention

\section{Review of Literature}

\subsection{Forensic Audit}

Forensic audit has been defined by the Institute of Forensic Auditors (IFA) as an activity that involves the collection, verification, analysis and reporting of data with the aim of collecting evidence to use in a court of law. 
The focus of forensic audit is the in-depth investigation and detection of fraud and it involves investigating the fraud and providing litigation support services in the court of law (Knezevic, 2015). Forensic auditing is the systematic application of auditing skills to situations or circumstances that have legal implications or consequences.

According to Dada, Owolabi and Okwu (2011), forensic auditing arises from the integration of accounting, investigative auditing, criminology and litigation services. Forensic auditors are experts in financial matters who are trained in detecting, investigating and deterring fraud and white collar crimes which are to be presented to court for legal action or to public discussion and debate (Eyisi \& Agbaeze, 2014). Forensic audit evidence collected and evaluated could be presented in a court of competent jurisdiction in a case of litigation and could be used to correct a situation that could lead to fraud. According to Enofe, Omagbon \& Ehigiator (2015), forensic audit focuses on the detection, analysis and communication of evidence of underlying financial and reporting events.

It should be noted that forensic audit service is useful not only as a reactive measure but also as a proactive measure to curb fraud in the bank. Reactive forensic auditing investigates any suspicion of fraud and if the suspicion is confirmed, the person(s) involved are identified, the findings are backed up with concrete evidences for disciplinary action or criminal proceedings. Proactive forensic auditing identifies mistakes and deviant financial transactions before they graduate into fraud. The proactive approach looks for fraud indicators and uses the philosophy of "catch fraud before it catches you". The proactive forensic auditing may revolve around a statutory audit, diagnostic tool and regulatory compliance.

\subsection{Bank Fraud}

Fraud could be seen as an intentional or deliberate distortion of financial statements or documents of an organization for undue advantages. Fraud is an intentional act by one or more individuals among management, employees or third parties which result in a misrepresentation of financial statements (Adeniji, 2004).

According to Nwankwo (2013), fraud is a global phenomenon that has been in existence for long and it increases every day by day. He notes that fraud is a deliberate act that causes a business or economy to suffer damages, often in the form of monetary losses.

Bank fraud has been said to be the use of illegal means or medium to obtain assets, money or property owned or held by a financial institution. It is a crime of obtaining money from depositors by posing as a bank. Bank fraud connotes actions that employ a scheme and for this person, it is sometimes seen as white-collar crime. Bank fraud is a criminal act that takes place where a person uses illegal means to receive money or assets from a bank, other financial institutions or depositors of a bank. In essence, it is the act of employing illegal means to obtain money or other assets held by a financial institution or the act of obtaining money or assets from people by posing as a financial institution. According to Nweze (2008), the main cause of bank fraud can be grouped into two. These are institutional factors and environmental factors. Institutional factors or causes are those that can be traced to internal environment of the financial institution while environmental factors are factors that are traceable to the banks' immediate and remote environment.

\subsection{Fraud Detection}

Fraud detection has been said to be part of an entity's overall anti-fraud strategy which entails prevention, detection and investigation. To detect is to uncover or reveal or find out the existence of something. Detection of fraud involves the actual identification of actual or potential fraud in an organization. It is the process of spotting the early signals or warning signs of possible fraud. It is a proactive risk assessment and reactive to fraud reports.

\subsection{Fraud Prevention}

To prevent is to keep or stop something from happening. Prevention is the action of stopping something from happening. Fraud prevention is the process of stopping the occurrence of fraud in an organization. It could involve the removal of the casual enabling factors that encourage frauds in an organization. Putting in place necessary measures to deter or stop or discourage fraud in an organization is what fraud prevention is all about.

\subsection{Theoretical Foundation for the Study}

There are many theories used for fraud detection, prevention and reduction. However, this study is anchored on two theories. These are the Police man theory and the Fraud Diamond. The Police man theory postulates that the forensic auditor is a policeman who has the duty of detecting and preventing frauds to mitigate incidences of frauds in corporate establishments. The fraud diamond theory was projected by Wolf and Hermanson (2004). This theory adds the fourth variable or element - capabilities to the three factor theory of fraud triangle. Without the right person with right capabilities, perpetrating fraud and executing its details will be difficult. 
They identified four observation traits for committing fraud. These are (i) authoritative position in the organization (ii) capacity to understand and exploit the organization's systems of accounting and internal control (iii) confidence that they will not be detected, or if caught, they will get out of it easily (iv) capability to deal with the stress created within the additional variable introduced in the fraud diamond theory, the organization and the auditors have better knowledge of employees' traits and abilities individually and this creates room for better assessment of the risk of fraudulent behaviours. Due to the capability of persons who engage in fraudulent activities, the need for skilled, trained and experienced experts like the forensic auditor becomes sacrosanct.

\section{Methodology}

The research design employed for this study was the survey design. The primary source of data collection was used. We used a properly structured questionnaire where responses to the questions were graded using 5 point likert scale with 5 - strongly agree, 4 -Agree, 3 - undecided, 2 - Disagree and 1 - strongly disagree. The sample of the study was 128 out of a population of 165 of the respondents. The questionnaire was administered to 142 respondents but 128 were returned. The data generated were analyzed using Ordinary Least Square (OLS) regression model.

\subsection{Model Specification}

The study looked at Bank Fraud (BKFD) as a function of Forensic Audit (FAD). FAD is proxied by Bank Fraud Detection (BFD) and Bank Fraud Prevention (BFP). The function is represented by:

Bank Fraud $=f($ Forensic Audit $)$

$B K F D=f(B F D, B F P)$

The above function can further be represented as :

$B K F D=\beta_{0}+\beta_{1} B F D+\beta_{2} B F P+\mu_{t}$

Where: $\mathrm{BKFD}=$ Bank fraud

$\mathrm{BFD}=$ Bank Fraud Detection

$\mathrm{BFP}=$ Bank Fraud Prevention

$\mu_{t}=$ Error term

$\beta_{0} \ldots \beta_{2}=$ Regression Co-efficient of the model used

\section{Results Interpretation}

Table1: Descriptive Statistics of the Variables

This section presents and discusses the descriptive statistics of the variables, as presented in Table 1

\begin{tabular}{|l|l|l|l|l|l|}
\hline variable & Obs & mean & Std. Dev. & Min & Max \\
\hline BFD & 128 & 10.2187 & 12.1324 & 1 & 86 \\
\hline BFP & 128 & 11.2890 & 14.9308 & 1 & 92 \\
\hline BKFD & 128 & 19.2109 & 23.2109 & 2 & 96 \\
\hline
\end{tabular}

Source: Researchers' Computation (2019) using STATA Version 12

Table 1 reveals that the (BKFD) of the banks ranged from $2 \%$ to a maximum of $96 \%$ and with average values of the dependent of $19.2 \%$ and the standard deviation is 23.4828 indicating lack of substantial variation. Other variables which are independent in the table also indicate some level of variability. On the overall Bank fraud prevention (BFP) has the highest standard deviation with about 14.9308 and Bank fraud detection (BFD) has the lowest standard deviation account for only 12.1324. These indicate that the bank fraud detection and Bank fraud prevention occupy $12.1324 \%$ and $14.9308 \%$ of the total fraud occurred. In order to examine the level of relationship between the dependent and independent variables, correlation matrix is used. Variance Inflation Factor (VIF) test is carried out also to find out whether or not multi-collinearity exists as a result of the relationship between the variables. The correlation matrix in Table 2 provides some insights into which of the independent variables are related to the BKFD.

\section{Table 2: Correlation Matrix}

Shows the summary of correlation coefficient between dependent variables (BKFD) and explanatory variables. From the table it was observed that multicollinearity was not a threat to the model variables 
Table 2: Correlation Matrix of Dependent and Independent Variables

\begin{tabular}{|l|l|l|l|}
\hline Variable & BFD & BFP & BKFD \\
\hline BFD & 1.0000 & & \\
\hline BFP & 0.0612 & 1.0000 & \\
\hline BKFD & 0.1020 & 0.0841 & 1.0000 \\
\hline
\end{tabular}

Source: Researchers' Computation (2019) using STATA Version 12

From Table 2, it is observed that the independent variables of the study correlate perfectly well (between 0.1020 and 0.0841). There is relationship among the independent variables that is large enough to pose the problem of singularity of data (Hassan, 2011). The extent of relationship among all the independent variables is therefore minimal and negligible.

The Table revealed a positive correlation coefficient between BKDF and bank fraud detection (0.1020) of listed deposit money banks in Nigeria during the period of investigation. The positive coefficient between BKFD and bank fraud detection (BFD) of the sampled banks is an indication that BKFD is associated with increase in bank fraud detection (BFD) of the banking sector during the study period. This relationship here indicated that BKFD has a strong influence on detecting fraud in the banking sector.

(BKFD) is also positively correlated with Bank fraud prevention (0.0841) of the banks in Nigeria during the study period. The higher positively coefficient between BKFD and bank fraud prevention in the bank in Nigeria suggests that BKFD is associated with BFP. This may be because forensic auditors possess bank's experience that enable them to detect questionable accounting practices of banks more easily than their counterparts. Forensic auditors also invest in relevant audit technology and training that give them an edge over their counterparts in practice.

Furthermore, it's also noted that after various surveys, through questionnaire the respondent analysis result shows that forensic auditors are significantly useful in fraud detection and prevention in the banking sector in Nigeria. Correspondingly From the hypothesis tested, it has been seen that forensic Auditor are very useful especially in the area of detecting fraud in the banking industry.

Table 3: Test of Multi-collinearity.

\begin{tabular}{|l|l|l|}
\hline Variable & VIF & 1/VIF \\
\hline BFD & 1.00 & 0.9962 \\
\hline BFP & 1.00 & 0.9962 \\
\hline Mean VIF & 1.00 & \\
\hline
\end{tabular}

Source: Researchers' Computation (2019) using STATA Version 12

In order to test how reliable our data is, we need for test, Multi-collinearity exists when the predictor variables are highly correlated among themselves. If the variables have VIF of above 10 and TV less than0.10, then there is a strong indication of the existence of excess correlation (Gujarati, 2004). With the above values of VIF that are less than 10 and the values of $\mathrm{TV}$ which are also more than 0.10 , there is therefore an absence of multi-collinearity.

Table 3 : Mutiple linear regression Analysis

\begin{tabular}{|l|l|l|l|l|l|l|}
\hline BKFD & Obs Coef. & $\begin{array}{l}\text { Bootstrap } \\
\text { Std.Err. }\end{array}$ & $\mathbf{Z}$ & $\mathbf{p}>\mathbf{z}$ & 95\% Conf. & interval \\
\hline BFD & .1881 & .0176 & 10.66 & 0.0000 & .1535 & .2222 \\
\hline BFP & .1229 & .0133 & 9.19 & 0.0000 & .0967 & .1491 \\
\hline Con_ & 15.9001 & 3.4568 & 4.60 & 0.0000 & 9.1248 & 22.6755 \\
\hline Prob > F & & & & 0.0041 & & \\
\hline R- Squared & & & & 0.8901 & & \\
\hline Adj R-square & & & & 0.8820 & & \\
\hline
\end{tabular}


Significant at the 0.05* level (1-tailed), Source: Researchers' computation (2019) using STATA Version 12.

Table 3 presents the regression results of the model equation of the dependent variable (BKFD) and independents as well as explanatory variables (Fraud detection and fraud prevention). The coefficient of "R-squared" shows $16 \%$ which indicate that the variables used in the model accounts for about $16 \%$ variation on BKFD as the dependent variable, whereas the remaining of the variation accounts for the outcome of other variables which were not considered by this model. It is also positively significant at $5 \%$. As such, the model equation can be inscribed as: BKFD $=15.900+$ $0.1881 \beta 1+0.1229+\varepsilon$. In evaluating the model of the regression equation, shows that, the relationship between BKFD is positive and significant, this can be justified with and $\mathrm{P}>|\mathrm{t}| 0.000$ and 0.000 respectively. Similarly the result of the coefficient 0.000 is positive, which also means that an improvement on forensic audit result to decrease in bank fraud in Nigeria banking industry. This infers that, fraud detection has a positive relationship with BKFD. So also the relationship between BKFD and BFP is positive and statistically significant, justifiable with $\mathrm{P}>|\mathrm{t}| 0.000$ which also has a positive coefficient of 0.1229 , which also implies that, BFP has a positive and statistically significant at $5 \%$ level of significance with BKFD. Meaning that both BKFD and BKFP also reduce bank fraud in the banking industry. The result is consistent with Enofe, Utomwen and Danjuma (2015) reveals that there is a need for forensic audit in the Nigerian banking system, Forensic audit is an effective tool for addressing financial crimes in the banking system and finally that conventional accounting techniques are not effective in curbing financial crimes. Imoniana, Antunes and Formigoni (2013) conclude that the idea that frauds have been least detected by forensic auditors begins to gain shape as forensic auditors are more adequately trained to detect and prevent fraud instead of emphasizing the traditional segregation of duties and safeguard.

\section{References}

Adeniji, A.A. (2004). Auditing and Investigation, Lagos: Value Analysis Consult.

Adeyemi, B. (2011). Bank Failure in Nigeria: A Consequence of Capital Inadequacy, Lack of Transparency and NonPerforming Loans. Banks and Banking Systems, 6 (1), 99.

Adeyemi, S. B.; Okpala, O. \& Dabor E.L. (2012). Factors Affecting Audit Quality in Nigeria. International Journal of Business and Social Sciences, 3 (20), 198-201.

Aguolu, O. (2008). Fundamentals of Auditing, (3 ${ }^{\text {rd }}$ ed.) Enugu: Institute for Development Studies, UNEC, 364, 368369.

Dada, S.O., Owolabi, S.A. \& Okwu, A.T. (2013). Forensic Accounting, A Panacea to Alleviation of Fraudulent Practices in Nigeria. International Journal of Business Managemetn and Economic Research 4(5).

Egbo,O. P. (2012). Universal Basis of Bank Failure-The Nigerian Case. Developing Country Studies, 2 (10), 125.

Enofe, A.O., Omagbon, P. \& Ehigiator, F.I. (2015). Forensic Audit and Corporate Fraud. International Institute of Academic Research and Development.

Eyisi, A.S. \& Agbaeze, E.K. (2014). The Impact of Forensic Auditors in Corporate Governance. International Journal of Development and Sustainability 3(2) 406

Knezevic, G. (2015). The Characteristics of Forensic Audit and Differences in Relation to External Audit. FINIZ 2015 Contemporary Financial Management. 203-204.

Modum, U. ;Ugwoke, R. O. \& Onyeanu, E. O. (2013). Audit Committees and Corporate Performance in Selected Companies Quoted in the Nigerian Stock Exchange: A Perception Analysis. Research Journal of Finance and Accounting, 4 (16), 115-116.

Nwankwo, O. (2013). Implications of Fraud on commercial Banks Performance in Nigeria. International Journal of business and Management, 8(15), 144.

Nweze, C. (2008). Bank Fraud Exposed with Cases and Preventive Measures. Control and Surveillance Association ltd, Lagos.

Okafor, C. N. (2012). Audit Quality and Auditors Independence. A paper presented at 2012 ANAN MCPD Programme.

Okafor, R.G. \& Onwumere, J.U.J. (2012). Issues and Challenges in Enhancing Efficient Entrepreneurial Accounting Education in Nigerian Universities. Developing Country Studies, 2 (11), 220.

Wolf, D. T. and Hermanson, D. R. (2004) Financial Crime - What Impact Has It On Kenya's Economy. International Journal of Economic Development, 12 (3), 89-91 